\title{
Prediction of Lip Changes after Incisor Retraction in Class II Division 1
}

\author{
1 Jutharat Jongphairotkhosit, ${ }^{2}$ Supanee Suntornlohanakul, ${ }^{3}$ Nattaporn Youravong
}

\begin{abstract}
Aim: To evaluate the relationship of lip changes in anteroposterior direction and incisor retraction in Thai female patients with class II division 1 malocclusion.

Materials and methods: The sample consisted of 100 pairs of pre- and posttreatment lateral cephalograms. All cephalograms were derived from class II division 1 Thai female adults who were treated with four premolar extraction and edgewise technique. Sixteen linear and eight angular measurements were made and evaluated for dental and lip changes. Paired t-test was used for testing the difference between before and after orthodontic treatment. Pearson correlation analysis was used for evaluating factors that correlate with lip changes and stepwise multiple linear regression was performed to make the prediction of lip changes and incisor retraction.
\end{abstract}

Results: There was a significant correlation between lip changes and incisor retraction. The prediction of upper and lower lip changes in antero-posterior direction was mainly described by the cervical point of upper incisors $(\mathrm{HcUl})\left(\mathrm{R}^{2}=0.29\right)$, the tip of lower incisors ( $\mathrm{HtLI}$ ) and lower lip thickness (LL thickness) $\left(R^{2}=0.48\right)$.

Conclusion: Ratios of upper and lower incisors at tip point to upper and lower lips retraction were 1:0.46 and 1:1, respectively. The coefficient of determination for predicting upper and lower lips was 0.29 and 0.48 showing low to moderate predictability for lip changes.

Keywords: Class II division 1, Incisor retraction, Lip changes, Thai female adults.

How to cite this article: Jongphairotkhosit J, Suntornlohanakul S, Youravong N. Prediction of Lip Changes after Incisor Retraction in Class II Division 1. Int J Experiment Dent Sci 2018;7(2):48-53.

Source of support: Nil

Conflict of interest: None

\section{INTRODUCTION}

Class II division 1 malocclusion is one of the malocclusions which orthodontic treatment is indicated. ${ }^{1}$ Outstanding characteristics of class II division 1 malocclusion are protruded upper incisors, increased overjet,

\footnotetext{
${ }^{1}$ Resident, ${ }^{2,3}$ Associate Professor

${ }^{1-3}$ Department of Preventive Dentistry, Prince of Songkla University, Hatyai, Songkhla, Thailand

Corresponding Author: Supanee Suntornlohanakul, Associate Professor, Department of Preventive Dentistry, Prince of Songkla University, Hatyai, Songkhla, Thailand, e-mail: supanee.s@psu.ac.th
}

and deep overbite. ${ }^{2}$ Different orthodontic treatment modalities can be applied to correct overall occlusal traits in class II division 1 malocclusion. In the adult, camouflage treatment is an option in the mild skeletal discrepancy. If camouflage treatment is being a treatment of choice, extraction of premolar, mainly upper first premolar, usually required.

The retraction of upper and lower anterior teeth can affect facial profile, especially at upper and lower lips. In the same that the facial profile may appear to be flatten after treatment. Therefore, the capability of the orthodontist to forecast what will be the facial profile after treatment is valuable for patient decision. From past to present, ratio scale is accepted in its ease to be used for the soft tissue prediction after incisor retraction. From Japanese subjects, Kasai $^{3}$ and Hayashida ${ }^{4}$ presented ratios of 1:0.42-0.45 and 1:1.29. In African, Caplan ${ }^{5}$ reported ratios of 1:0.83 and 1:0.57. In Caucasians, Rudee ${ }^{6}$ suggested ratios of 1:0.34 and 1:1.69. Several studies ${ }^{3-23}$ have shown that the lip changes were influenced not only by the number of incisors retracted but also by growth, malocclusion, sex, treatment modalities, lip morphology, and ethnicity.

No previous studies presented lip changes in Thai patients with class II division 1 malocclusion. Therefore, this study will provide the prediction of lip changes in anteroposterior direction after incisor retraction providing information for advising patients about treatment alternatives in class II division 1 malocclusion.

The purpose of this study was to evaluate lip changes in the anteroposterior direction after incisor retraction in Thai female patients with class II division 1 and make the predictions.

\section{MATERIALS AND METHODS}

The research protocol was approved by the Ethics Committee of Prince of Songkla University. The sample consisted of 100 pairs of pre- and posttreatment lateral cephalograms. The radiographs were selected from cephalograms of patients enrolled at Orthodontic Clinic, Faculty of Dentistry, Prince of Songkla University between 2004-2015. Inclusion criteria of the patients were female aged 17 years or more and had class II division 1 malocclusion (overjet $>4 \mathrm{~mm})^{24}$ at the beginning and 
canine class I (normal overjet and overbite) after complete treatment. All radiographs were in good quality, without any appliances, teeth positioned in centric occlusion, relaxed lip position ${ }^{25}$ and were performed with the same $\mathrm{X}$-ray device.

The reference line $\mathrm{e}^{21,22}$ was established by constructing sella-nasion (SN) line $-7^{\circ}$ and a S-true vertical line was constructed as perpendicular to the S-true horizontal line though the sella. All reference points and planes are defined and illustrated in Figure 1 and Table 1. Sixteen linear and eight angular measurements are shown in Figure 2 and Table 2.

\section{Measurement Error and Reliability}

All cephalograms were traced by hand on matte acetate and were performed by one researcher to minimize bias. For quality control, ten cephalograms were randomly selected to test measurement errors by Dahlberg's formula ${ }^{26}$ and intraclass correlation coefficients (ICC) at 2-week intervals.

\section{Statistical Analysis}

Kolmogorov-Smirnov test was used to test normality of all variables. Paired t-test was used to evaluate dental and lip changes before and after treatment. Pearson correlation coefficient and stepwise multiple regression were performed to determine the lip prediction. The statistical package for social sciences (SPSS) statistical bass 17.0 for Windows EDU S/N 5065845 (SPSS Inc., Chicago, USA)was used in the analysis.

\section{RESULTS}

The mean age of patients was $21.5 \pm 4.98$ years. Measurement error from Dahlberg's formula ${ }^{26}$ was $0.14 \mathrm{~mm}$ and 0.14 degree and ICC was 0.9. Therefore, reliability of

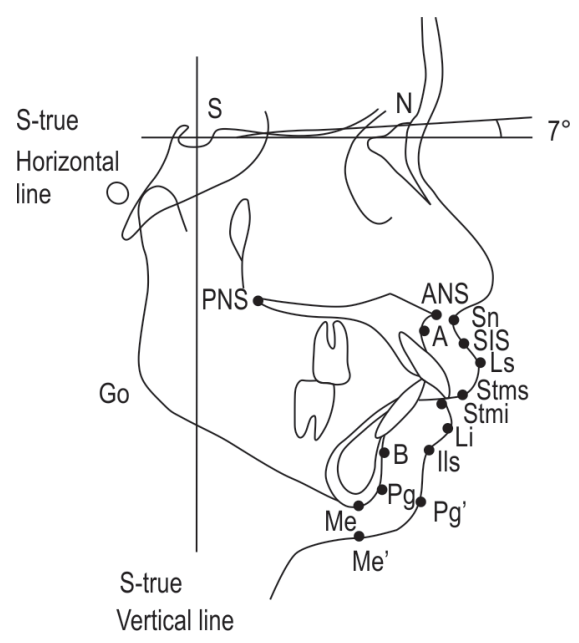

Fig. 1: Reference points and planes the measurement was acceptable. Means and standard deviations in pretreatment are shown in Table 3. Paired t-test of all linear and angular measurements showed statistically significant change $(p<0.05)$ except LI-NB, LL thickness and lower facial height (Table 4). Pearson correlation coefficient presented in Table 5 shows significant positive and negative correlations between dental and lip changes. Stepwise multiple regression shown in Table 6 indicates that upper lip retraction could be influenced by the cervical point of upper incisors $\left(\mathrm{R}^{2}=\right.$ 0.29 ). Lower lip retraction was influenced by the tip of lower incisors and lower lip thickness in pretreatment $\left(\mathrm{R}^{2}=0.48\right)$.

Table 1: Reference points of hard tissue and soft tissue and reference planes

\begin{tabular}{ll}
\hline $\begin{array}{l}\text { Reference points/ } \\
\text { planes }\end{array}$ & Definitions \\
\hline $\begin{array}{l}\text { Hard tissues } \\
\text { S (sella) }\end{array}$ & $\begin{array}{l}\text { Midpoint within sella turcica } \\
\text { N (nasion) }\end{array}$ \\
ANS & $\begin{array}{l}\text { Most anterior point of frontonasal suture in } \\
\text { median plane }\end{array}$ \\
PNS & $\begin{array}{l}\text { Most anterior point of maxilla in maxillary } \\
\text { Most posterior point of maxilla in maxillary }\end{array}$ \\
A (subspinale) & $\begin{array}{l}\text { Plane } \\
\text { maint at deepest midline concavity on }\end{array}$ \\
B (supramentale) & $\begin{array}{l}\text { Point at deepest midline concavity } \\
\text { on mandibular symphysis between } \\
\text { infradentale and pogonion }\end{array}$ \\
Go (gonion) & Midpoint between pogonion and menton \\
Pg(pogonion) & Most anterior point of bony chin \\
Me (menton) & Most inferior point of bony chin \\
Soft tissue & Point at junction of columella and upper lip \\
Sn (subnasale) & Most inferior point of upper lip
\end{tabular}

superius)

Stmi (stomion Most superior point of lower lip

inferius)

Ls (labrale superior)

Most anterior point on convexity of upper lip

Li (labrale inferior) Most anterior point on convexity of lower lip

SIs(superior Point of greatest concavity between labrale sulcus) subnasale and labrale superior

Ils (inferior labrale Point of greatest concavity between labrale sulcus)

Pg' (soft tissue pogonion)

Me' (soft tissue Most inferior point of soft tissue chin menton)

Reference planes Definitions

SN plane

Line extending between nasion and midpoint of sella turcica

S-true horizontal Horizontal plane running through sella line turcica and intersection of SN plane- $7^{\circ}$

S-true vertical line Vertical plane running through sella turcica and perpendicular to S-true horizontal line 

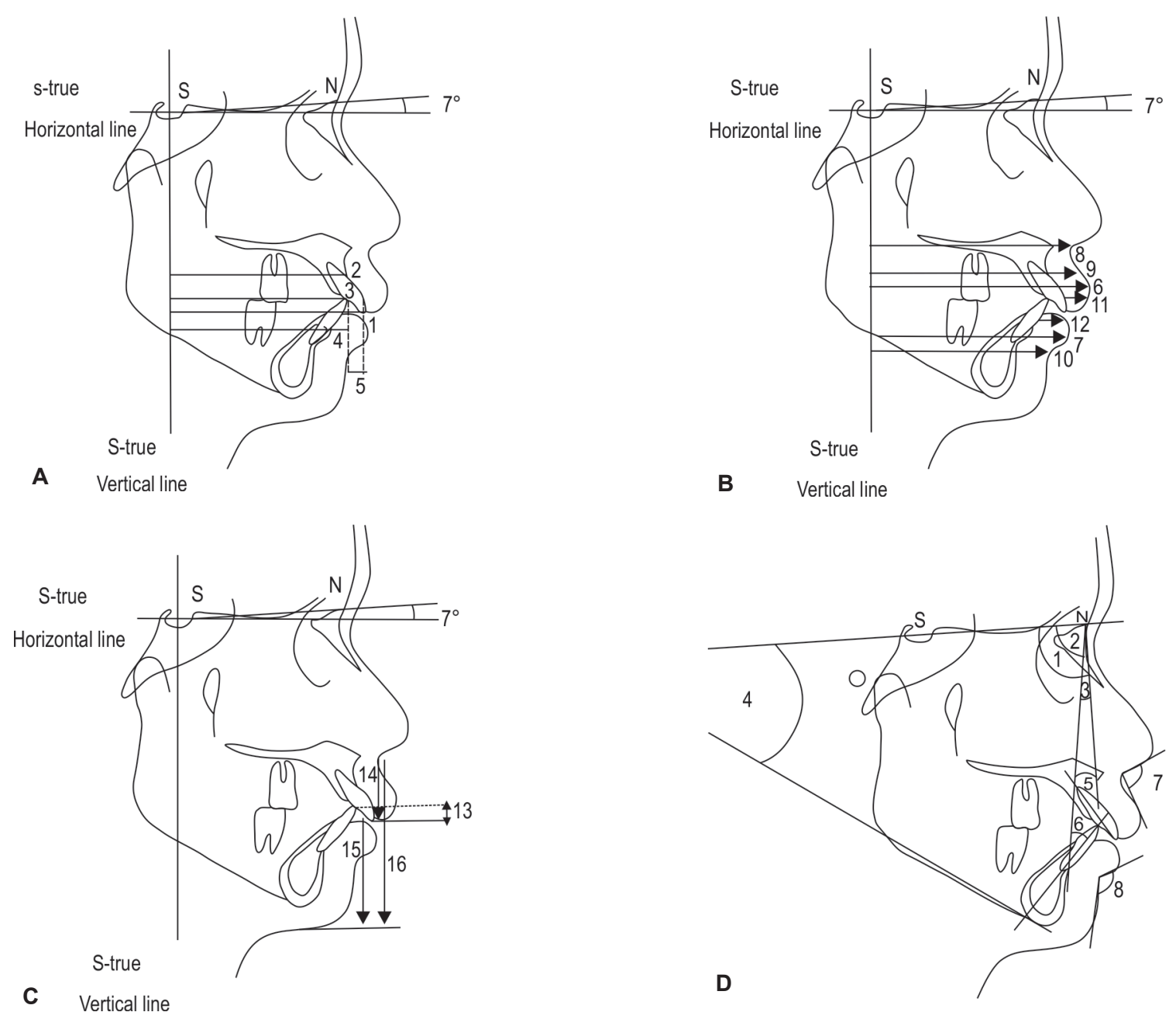

Figs 2A to D: (A) Anteroposterior line measurements of hard tissue:1.H-tUI 2.H-cUI 3.H-tLI 4. H-cLI 5. Overjet; (B) Anteroposterior line measurements of soft tissue: 6. H-U-lip 7. H-L-lip 8. H-subnasale 9. H-sulcus superioris $10 . \mathrm{H}$-sulcus inferioris 11 . Upper lip thickness 12. Lower lip thickness; (C) Vertical line measurements of hard tissue and soft tissue: 13. Overbite 14. Upper lip length 15. Lower lip length 16. Lower facial height; (D) Angular measurements: 1. SNA 2. SNB 3. ANB 4. Mandibular plane 5. UI-NA 6. LI-NB 7. Nasolabial angle 8. Labiomental angle

\section{DISCUSSION}

The restriction of cephalograms in this study was intended to reduce the influence of confounding factors. ${ }^{3-23}$ This study was limited to adult patients since facial growth could affect skeletal and soft tissue changes. Gender ${ }^{14,17-19}$ and ethnicity ${ }^{5,9,11}$ also affect the physical characteristics of the lip. Most of the patients who need orthodontic treatment were females ${ }^{27}$ because of more esthetic concern.Atisook and Chuacharoen ${ }^{27}$ showed that females had a significantly higher demand for orthodontic treatment than males. So, this study recruited only Thai female subjects. $\mathrm{SN}-7^{\circ}$ was used for reference plane ${ }^{2,21,22}$ since it could represent the true horizontal and vertical lines and reduce variability between studies.

\section{Upper Lip Changes}

Many studies ${ }^{9,14,18-20}$ have predicted soft tissue profile changes after orthodontic treatment by trying to build the relationship between incisor retraction and lip changes as a ratio to guide treatment planning. Tip and cervical point of incisors were commonly used for reference points to predict lip changes. The previous studies ${ }^{6,7}$ stated that this position was highly predictive but some studies ${ }^{2,3}$ found poorer predictive ability. The current study found a moderate correlation between upper incisor retraction at the tip and cervical point with upper lip retraction ( $r=0.48$ and 0.54 , respectively).

The ratio of incisor retraction at the cervical point to upper lip retraction in this study was 1:0.88, which is similar that of Ramos, ${ }_{1}^{10}$ who studied adolescent Brazilian patients (the ratio was 1:0.7-0.75) but higher than that of Kasai $^{3}$ and Hayashida ${ }^{4}$ in adult Japanese patients (the ratio was 1:0.42-0.45).

The multiple regression analysis found that upper lip retraction was associated with upper incisor retraction at 
Prediction of Lip Changes after Incisors Retraction in Class II Division 1

Table 2: Anteroposterior and vertical measurements of hard and soft tissue

\begin{tabular}{|c|c|}
\hline Variables & Definitions \\
\hline \multicolumn{2}{|l|}{$\begin{array}{l}\text { Anteroposterior } \\
\text { measurements }\end{array}$} \\
\hline $\mathrm{H}$-tU1 & Tip of upper incisor to vertical line \\
\hline $\mathrm{H}-\mathrm{cU} 1$ & $\begin{array}{l}\text { Cervical point of upper incisor to } \\
\text { vertical line }\end{array}$ \\
\hline $\mathrm{H}-\mathrm{tL} 1$ & Tip of lower incisor to vertical line \\
\hline $\mathrm{H}-\mathrm{cL} 1$ & $\begin{array}{l}\text { Cervical point of lower incisor to } \\
\text { vertical line }\end{array}$ \\
\hline H-U-lip & $\begin{array}{l}\text { Most anterior point of upper lip to } \\
\text { vertical line }\end{array}$ \\
\hline H-L-lip & $\begin{array}{l}\text { Most anterior point of lower lip to } \\
\text { vertical line }\end{array}$ \\
\hline H-subnasale & Subnasale to vertical line \\
\hline $\begin{array}{l}\mathrm{H} \text {-sulcus } \\
\text { superioris }\end{array}$ & Sulcus superioris to vertical line \\
\hline $\begin{array}{l}\mathrm{H} \text {-sulcus } \\
\text { inferioris }\end{array}$ & Sulcus inferioris to vertical line \\
\hline $\begin{array}{l}\text { Upper lip } \\
\text { thickness }\end{array}$ & $\begin{array}{l}\text { Middle point of labial surface of upper } \\
\text { incisor to Ls (labrale superior) }\end{array}$ \\
\hline $\begin{array}{l}\text { Lower lip } \\
\text { thickness }\end{array}$ & $\begin{array}{l}\text { Middle point of labial surface of lower } \\
\text { incisor to Li (labrale inferior) }\end{array}$ \\
\hline \multicolumn{2}{|l|}{$\begin{array}{l}\text { Vertical } \\
\text { measurements }\end{array}$} \\
\hline $\begin{array}{l}\text { Lower facial } \\
\text { height }\end{array}$ & $\begin{array}{l}\text { Sn (subnasale) to Stms that parallel to } \\
\text { vertical line }\end{array}$ \\
\hline Lower lip length & $\begin{array}{l}\text { Stmi to Me' (soft tissue menton) that } \\
\text { parallel to vertical line }\end{array}$ \\
\hline $\begin{array}{l}\text { Lower facial } \\
\text { height }\end{array}$ & Sn to Me' that parallel to vertical line \\
\hline
\end{tabular}

cervical point $\left[\Delta \mathrm{H}-\mathrm{U}-\mathrm{lip}=0.55(\Delta \mathrm{H}-\mathrm{cUI})-1.2\right.$, adjusted $\mathrm{R}^{2}=$ 0.29] which was similar to to $\operatorname{Ramos}^{10}$ and Hayashida.
Table 3: Means and standard deviations of pre-treatment variables

\begin{tabular}{|c|c|c|}
\hline Pre-treatment variables & Mean & $S D$ \\
\hline \multicolumn{3}{|l|}{ Skeletal } \\
\hline Mandibular plane $\left({ }^{\circ}\right)$ & 84.77 & 3.7 \\
\hline $\operatorname{SNB}\left({ }^{\circ}\right)$ & 80.23 & 3.76 \\
\hline ANB $\left({ }^{\circ}\right)$ & 4.57 & 1.92 \\
\hline Mandibular plane $\left({ }^{\circ}\right)$ & 35.57 & 6.5 \\
\hline \multicolumn{3}{|l|}{ Dental } \\
\hline Overbite (mm) & 30.22 & 7.43 \\
\hline LI-NB $\left({ }^{\circ}\right)$ & 34.87 & 6.08 \\
\hline Overjet (mm) & 6.16 & 1.94 \\
\hline Overbite (mm) & 3.38 & 1.56 \\
\hline Soft tissue & & \\
\hline $\begin{array}{l}\mathrm{H} \text {-sulcus inferioris (the last } \\
\text { row) }\end{array}$ & 70.42 & 6.78 \\
\hline UL thickness (mm) & 10.77 & 1.68 \\
\hline LL thickness (mm) & 13.79 & 1.71 \\
\hline UL length (mm) & 23.07 & 2.17 \\
\hline LL length (mm) & 45.14 & 3.43 \\
\hline Nasolabial angle $\left({ }^{\circ}\right)$ & 85.13 & 10.15 \\
\hline Labiomental angle $\left({ }^{\circ}\right)$ & 112.2 & 16.06 \\
\hline $\mathrm{H}$-subnasale (mm) & 84.78 & 4.64 \\
\hline $\mathrm{H}$-sulcus superioris (mm) & 87.49 & 4.92 \\
\hline $\mathrm{H}$-sulcus inferioris ( $\mathrm{mm}$ ) & 79.06 & 6.81 \\
\hline
\end{tabular}

This ratio and equation are different from those of the previous studies $3,5,6$ due to the structure of soft tissues and physical characteristics of the lip that are different in each race. Burstone ${ }^{25}$ recommended that lip should be in a relaxed position when cephalograms are taken to reduce variability in lip posture.

Table 4: Means and standard deviations of pre- and posttreatment variables and treatment changes

\begin{tabular}{|c|c|c|c|c|c|c|c|c|}
\hline \multirow[b]{2}{*}{ Variables } & \multicolumn{2}{|c|}{ Pretreatment } & \multicolumn{2}{|c|}{ Posttreatment } & \multicolumn{4}{|c|}{ Changes } \\
\hline & Mean & $S D$ & Mean & $S D$ & Mean & $S D$ & Min & Max \\
\hline \multicolumn{9}{|l|}{ Hard tissue } \\
\hline H-tUI (mm) & 81.12 & 5.93 & 74.2 & 5.72 & $-6.92^{a}$ & 2.22 & -7.36 & -6.48 \\
\hline $\mathrm{H}$-cUI (mm) & 77.62 & 4.98 & 74.03 & 4.91 & $-3.59^{a}$ & 1.39 & -3.86 & -3.31 \\
\hline H-tLI (mm) & 74.9 & 5.66 & 71.42 & 5.53 & $-3.48^{\mathrm{a}}$ & 2.01 & -3.88 & -3.08 \\
\hline H-cLI (mm) & 71.06 & 6.05 & 68 & 6.32 & $-3.06^{a}$ & 1.84 & -3.43 & -2.7 \\
\hline UI-NA $\left({ }^{\circ}\right)$ & 30.22 & 7.42 & 16.21 & 6.97 & $-14^{a}$ & 6.8 & -15.36 & -12.66 \\
\hline LI-NB $\left({ }^{\circ}\right)$ & 34.87 & 6.09 & 33.76 & 6.46 & $-1.11^{\mathrm{c}}$ & 6.85 & -2.47 & 0.25 \\
\hline \multicolumn{9}{|l|}{ Soft tissue } \\
\hline H-U-lip (mm) & 91.86 & 5.55 & 88.69 & 5.62 & $-3.17^{a}$ & 1.4 & -3.45 & -2.9 \\
\hline H-L-lip (mm) & 88.2 & 6.3 & 84.55 & 6.33 & $-3.64^{a}$ & 1.76 & -3.99 & -3.3 \\
\hline UL thickness (mm) & 10.77 & 1.68 & 12.75 & 2.04 & $1.98^{\mathrm{a}}$ & 1.36 & 1.71 & 2.25 \\
\hline LL thickness (mm) & 13.79 & 1.71 & 13.74 & 1.55 & $-0.05^{\mathrm{c}}$ & 1.6 & -0.37 & 0.27 \\
\hline UL length (mm) & 23.07 & 2.17 & 24.39 & 2 & $1.32^{\mathrm{a}}$ & 1.44 & 1.03 & 1.6 \\
\hline LL length (mm) & 45.14 & 3.43 & 45.98 & 3.56 & $0.83^{a}$ & 1.85 & 0.47 & 1.2 \\
\hline Interlabial gap (mm) & 2.84 & 2.49 & 0.93 & 1.59 & $-1.92^{\mathrm{a}}$ & 2.38 & -2.39 & -1.45 \\
\hline Nasolabial angle $\left({ }^{\circ}\right)$ & 85.13 & 10.15 & 97.89 & 11.19 & $12.76^{a}$ & 5.98 & 11.57 & 13.94 \\
\hline Labiomental angle $\left({ }^{\circ}\right)$ & 112.2 & 16.06 & 118.25 & 16.97 & $6.05^{a}$ & 9.81 & 4.09 & 7.99 \\
\hline Lower facial height (mm) & 70.42 & 6.78 & 70.56 & 6.71 & $0.14^{\mathrm{C}}$ & 1.32 & -0.12 & 0.4 \\
\hline H-subnasale (mm) & 84.78 & 4.64 & 84.69 & 4.64 & $-0.09^{b}$ & 0.42 & -0.17 & -0.00 \\
\hline $\mathrm{H}$-sulcus superioris (mm) & 87.49 & 4.92 & 85.49 & 5.1 & $-2.00^{\mathrm{a}}$ & 1.1 & -2.22 & -1.79 \\
\hline $\mathrm{H}$-sulcus inferioris (mm) & 79.06 & 6.81 & 77.32 & 6.98 & $-1.74^{a}$ & 1.55 & -2.05 & -1.43 \\
\hline
\end{tabular}

${ }^{\mathrm{a}} p<0.01,{ }^{\mathrm{b}} p<0.05,{ }^{\mathrm{c}}$ not significant from paired t-test 
Table 5: Pearson correlation coefficient between lip and hard tissue changes, soft tissue and hard tissue of pretreatment variables

\begin{tabular}{|c|c|c|c|c|}
\hline Variables & $H$-U-lip & H-L-lip & V-U-lip & $V$-L-lip \\
\hline \multicolumn{5}{|l|}{ Hard tissue (changes) } \\
\hline $\mathrm{H}$-tUI (mm) & $0.48^{a}$ & $0.32^{\mathrm{a}}$ & $-0.28 a$ & -0.02 \\
\hline $\mathrm{H}-\mathrm{cUI}(\mathrm{mm})$ & $0.54^{\mathrm{a}}$ & $0.27^{a}$ & $-0.28 a$ & -0.00 \\
\hline $\mathrm{H}$-tLI (mm) & $0.24^{\mathrm{b}}$ & $0.52^{\mathrm{a}}$ & $-0.22 b$ & -0.05 \\
\hline $\mathrm{H}-\mathrm{cLI}(\mathrm{mm})$ & $0.35^{\mathrm{a}}$ & $0.50^{\mathrm{a}}$ & -0.19 & 0.07 \\
\hline \multicolumn{5}{|l|}{ Hard tissue (pretreatment) } \\
\hline UI-NA $\left(^{\circ}\right)$ & -0.03 & 0.13 & 0.13 & 0.06 \\
\hline $\operatorname{LI}-\mathrm{NB}\left({ }^{\circ}\right)$ & -0.06 & -0.19 & 0.06 & 0.13 \\
\hline Overjet (mm) & $-0.23^{b}$ & 0.09 & 0.15 & -0.08 \\
\hline Overbite (mm) & -0.10 & -0.08 & -0.12 & $-0.24^{b}$ \\
\hline $\operatorname{SNA}\left({ }^{\circ}\right)$ & 0.11 & 0.02 & 0.13 & -0.07 \\
\hline $\operatorname{SNB}\left({ }^{\circ}\right)$ & 0.17 & 0.12 & 0.17 & -0.04 \\
\hline ANB $\left({ }^{\circ}\right)$ & -0.18 & -0.20 & -0.07 & -0.06 \\
\hline Mandibular plane $\left({ }^{\circ}\right)$ & -0.04 & -0.06 & -0.03 & 0.10 \\
\hline \multicolumn{5}{|l|}{ Soft tissue (pretreatment) } \\
\hline UL thickness (mm) & -0.06 & -0.02 & -0.13 & -0.03 \\
\hline LL thickness (mm) & -0.11 & $-0.38^{a}$ & -0.18 & -0.18 \\
\hline UL length (mm) & -0.00 & $-0.27^{a}$ & $-0.44^{\mathrm{a}}$ & $-0.30^{\mathrm{a}}$ \\
\hline LL length (mm) & 0.06 & -0.17 & 0.06 & $-0.21^{a}$ \\
\hline Nasolabial angle $\left({ }^{\circ}\right)$ & 0.09 & -0.04 & $-0.20^{b}$ & 0.03 \\
\hline Labiomental angle $\left({ }^{\circ}\right)$ & 0.16 & -0.02 & $-0.21^{b}$ & -0.14 \\
\hline Lower facial height (mm) & 0.06 & -0.06 & 0.07 & 0.05 \\
\hline H-subnasale (mm) & -0.03 & 0.03 & -0.03 & -0.02 \\
\hline H-sulcus superioris (mm) & -0.06 & 0.03 & 0.03 & -0.03 \\
\hline $\mathrm{H}$-sulcus inferioris (mm) & 0.07 & 0.02 & 0.10 & -0.06 \\
\hline
\end{tabular}

${ }^{\mathrm{a}} \mathrm{p}<0.01,{ }^{\mathrm{b}} p<0.05$

Table 6: Stepwise multiple linear regression analysis for predicting upper or lower lip changes

\begin{tabular}{|c|c|c|c|c|c|c|c|}
\hline \multirow{2}{*}{ Model } & & \multicolumn{2}{|c|}{ Unstandardized coefficients } & \multirow[b]{2}{*}{$t$-test } & \multirow{2}{*}{$\begin{array}{l}\text { Level of } \\
\text { significance }\end{array}$} & \multicolumn{2}{|c|}{$95 \%$ confidence interval for $B$} \\
\hline & & Beta & Standard error & & & Lower bound & Upper bound \\
\hline $\begin{array}{l}\mathrm{H} \text {-U-lip } \\
\left(\mathrm{R}^{2}=0.29\right)\end{array}$ & $\begin{array}{l}\text { Constant } \\
\Delta \mathrm{H}-\mathrm{cUl}\end{array}$ & $\begin{array}{l}-1.212 \\
0.546\end{array}$ & $\begin{array}{l}0.333 \\
0.087\end{array}$ & $\begin{array}{l}-3.642 \\
6.302\end{array}$ & $\begin{array}{l}<0.001 \\
<0.001\end{array}$ & $\begin{array}{l}-1.873 \\
0.374\end{array}$ & $\begin{array}{l}-0.552 \\
-0.718\end{array}$ \\
\hline $\begin{array}{l}\Delta \mathrm{H} \text {-L-lip } \\
\left(\mathrm{R}^{2}=0.48\right)\end{array}$ & $\begin{array}{l}\text { Constant } \\
\Delta \mathrm{H} \text {-tLI } \\
\text { LLthickness }\end{array}$ & $\begin{array}{l}4.548 \\
0.507 \\
-0.466\end{array}$ & $\begin{array}{l}1.106 \\
0.065 \\
0.076\end{array}$ & $\begin{array}{l}4.113 \\
7.833 \\
-6.135\end{array}$ & $\begin{array}{l}<0.001 \\
<0.001 \\
<0.001\end{array}$ & $\begin{array}{l}2.353 \\
0.378 \\
-0.617\end{array}$ & $\begin{array}{l}6.742 \\
0.635 \\
-0.315\end{array}$ \\
\hline
\end{tabular}

Predictive equations: $Y$ (dependents) $=$ constant $+(1 \mathrm{st})+(2 \mathrm{nd})$

$\mathrm{H}$, horizontal measurements; $\mathrm{V}$, vertical measurements; $\mathrm{R}^{2}$, coefficient of determination

\section{Lower Lip Changes}

The results showed moderate correlation coefficient between lower incisor retraction at tip point and cervical point of lower incisor with lower lip retraction $(r=0.52$ and 0.50 , respectively). This study presented the ratio of lower incisor retraction at tip point to lower lip retraction as 1:1, that was similar to that of Roos ${ }^{21}$ (ratio was 1:0.9) but was lower than those of $\mathrm{Kasai}^{3}$ (ratio was 1:1.29) and Rudee $^{6}$ (ratio was 1:1.69). Also, the lower lip also showed more adaptation to dental change than did the upper lip. Other reports ${ }^{2,28}$ indicated that upper lip has a complex anatomy of muscles related to the nose. Thus, lower lip change was more dependent on the hard tissue than in the upper lip. Roos ${ }^{21}$ found that upper lip retraction was limited by tip point of upper incisor retraction. From the results, upper incisor retraction could be related to the lower lip that was usually found behind the upper incisors (lip trapping) in class II division 1. After upper incisor retraction, the lower lip showed greater change. However, the change also depended on the response of the soft tissue in each patient.

Multiple regression analysis showed that the lower lip retraction was associated with tip point of lower incisors and the lower lip thickness before treatment $[\Delta \mathrm{H}-\mathrm{L}$-lip $=$ $0.51\left(\Delta \mathrm{H}\right.$-tLI) -0.47 (LL thickness) +4.55 , adjusted $\left.\mathrm{R}^{2}=0.48\right]$. The thickness of lower lip before treatment was another factor $^{11}$ affecting the prognosis of the lower lip, corresponding with previous reports. ${ }^{12,28}$

Upper and lower lip changes in this study were consistent with Hershey, who found that the lower lip had changed more than upper lip because lower lip had self-supporting anatomy and upper lip depended on other structures. ${ }^{7}$ Correlation analysis between upper and lower incisor retraction showed low and moderate ability to predict lip response (adjusted $R^{2}=0.29$ and 0.48 , respectively). 
This study showed that lip responses could be predicted more accurately using multivariate regression models due to controlling various factors. These models could help the orthodontist in treatment planning.

However, this study has some limitations. The coefficients of determination of model predictions in this study were less than that of previous study ${ }^{4}$ since some variables were not possibly included to be predictors, i.e., lips to E-line, occlusal plane-SN and other uncontrolled factors such as lips strain. These factors could result in a higher prediction of lip change in the model. This study shows the relationship between lip changes and incisor retraction only in anteroposterior direction because most of the orthodontic treatment in class II division 1 is to reduce overjet and improve lip protrusion. A further study should include other factors that may affect lip retrusion. However, the results of this study could be generalized to Asian females with class II division 1 who were treated with a conventional four-premolar extraction orthodontic treatment.

\section{Clinical Application}

A clinician can evaluate the changes of lips using the predictive equations and can create visual treatment objective (VTO) to assist in treatment planning. This information will be more beneficial for patients as a treatment alternative. In other words, if the position of lips cannot be corrected, the surgical plan may be another choice of treatment.

\section{CONCLUSION}

The ratios of upper and lower incisor retraction to upper and lower lip retraction in Thai female with class II division 1 were 1:0.46 and 1:1. The multiple regression equations were as follows:

- $\Delta$ H-U-lip $=0.55(\Delta \mathrm{H}-\mathrm{cUI})-1.2$

- $\Delta$ H-L-lip $=0.51(\Delta \mathrm{H}$-tLI)-0.47 (LLthickness) +4.55

\section{REFERENCES}

1. Mitchell L. An introduction to orthodontics. New York: Oxford University Press; 2007. p. 100-109

2. Bishara SE. Class II Malocclusion: Diagnostic and Clinical Considerations With and Without Treatment. Semin Orthod 2006;12:11-24

3. Kasai K. Soft tissue adaptability to hard tissues in facial profiles. Am J Orthod Dentofacial Orthop 1998;113(6):674-84.

4. Hayashida H, Ioi H, Nakata S, et al. Effects of retraction of anterior teeth and initial soft tissue variables on lip changes in Japanese adults. Eur J Orthod 2011;33(4):419-426.

5. Caplan MJ, Shivapuja PK. The effect of premolar extractions on the soft-tissue profile in adult African American females. Angle Orthod 1997;67(2):129-136.

6. Rudee DA. Proportional profile changes concurrent with orthodontic therapy. Am J Orthod 1964;50(6):421-434.
7. Hershey HG. Incisor tooth retraction and subsequent profile change in postadolescent female patients. Am J Orthod 1972; 61(1):45-54.

8. Yogosawa F. Predicting soft tissue profile changes concurrent with orthodontic treatment. Angle Orthod 1990;60(3): 199-206.

9. Brock RA, Taylor RW, Buschang PH, et al. Ethnic differences in upper lip response to incisor retraction. Am J Orthod Dentofacial Orthop 2005;127(6):683-691.

10. Ramos AL, Sakima MT, dos Santos-Pinto A, et al. Upper lip changes correlated to maxillary incisor retraction- a metallic implant study. Angle Orthod 2005;75(4):499-505.

11. Chaiyaraksa P, Viteporn S. Dentoskeletal and facial profile changes following orthodontic treatment with extraction and non-extraction in Class II division 1 patients. J Dent Assoc Thai 2010;60(3):169-179.

12. Zierhut EC, Joondeph DR, Artun J, et al. Long-term profile changes associated with successfully treated extraction and nonextraction Class II Division 1 malocclusions. Angle Orthod 2000;70(3):208-219.

13. Oliver BM. The influence of lip thickness and strain on upper lip response to incisor retraction. Am J Orthod 1982;82(2): 141-149.

14. Al-Hamdany AK. Integumental lips' height and separation in different Angle's classes of malocclusions. Al-Rafidain Dent J 2007;7(1):38-49.

15. Nanda RS, Meng H, Kaplia S, et al. Growth changes in the soft tissue facial profile. Angle Orthod 1990;60(3): 177-190.

16. Hoffelder LB, de Lima EM, Martinelli FL, et al. Soft-tissue changes during facial growth in skeletal Class II individuals. Am J Orthod Dentofacial Orthop 2007;131(4):490-495.

17. Bishara SE, Jakobsen JR, Hession TJ, et al. Soft tissue profile changes from 5 to 45 years of age. Am J Orthod Dentofacial Orthop 1998;114(6):698-706.

18. Subtelny JD. A longitudinal study of soft tissue facial structures and their profile characteristics defined in relation to underlying skeletal structures. Am J Orthod 1959;45(7):481-507.

19. Huggins DG, McBride LJ. The Influence of the upper incisor position on soft tissue facial profile. Br J Orthod 1975;2:141-146.

20. Bloom LA. Perioral profile changes in orthodontic treatment. Am J Orthod 1961;47(5):371-379.

21. Roos N. Soft-tissue profile changes in Class II treatment. Am J Orthod 1977;72(2):165-175.

22. Rains MD, Nanda R. Soft-tissue changes associated with maxillary incisor retraction. Am J Orthod 1982;81(6):481-488.

23. Scott Conley R, Jernigan C. Soft tissue changes after upper premolar extraction in Class II camouflage therapy. Angle Orthod 2006;76(1):59-65.

24. Sorathesn K. Craniofacial Norm for Thai in Combined Orthodontic Surgical Procedure.J Dent Assoc Thai 1988;38(5):190-201.

25. Burstone CJ. Lip posture and its significance in treatment planning. Am J Orthod 1967;53:262-284.

26. Galvao de S, Christina M, Ricardo J, Capobiango. Dahlberg formula-a novel approach for its evaluation. Dental Press J Orthod 2012;7(1):115.

27. Atisook P, Chuacharoen R. The relationship between demand and need for orthodontic treatment in high school students in Bangkok. J Med Assoc Thai 2014;97(7):758-766.

28. Maetevorakul S, Viteporn S. Factors influencing soft tissue profile changes following orthodontic treatment in patients with Class II Division 1 malocclusion. Prog Orthod 2016; 17:13. 